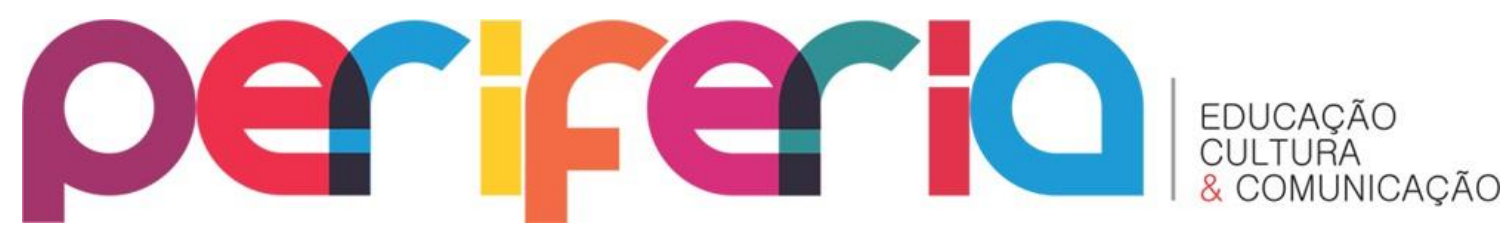

\title{
PRÁTICAS DOCENTES NA EDUCAÇÃO DE JOVENS E ADULTOS: CONSCIENTIZAÇÃO OU CONVERSÃO?
}

\author{
Alessandra Nicodemos ${ }^{1}$ \\ Universidade Federal do Rio de Janeiro
}

\section{RESUMO}

O presente artigo pretende estabelecer o debate das possibilidades de práticas docentes comprometidas com a transformação das relações educativas e societárias em espaços formais de escolarização para jovens e adultos trabalhadores. Esse esforço e esse compromisso político, por parte dos docentes, estão fortemente vinculados ao pensamento freiriano e aos pressupostos da Educação Popular. O debate será estabelecido a partir da categoria conscientização, em diálogo com autores de matrizes crítica e conservadora, a saber: Paulo Freire, Miguel Arroyo, Marilena Chauí, Giovanni Semeraro, Hugo Lovisolo e Hannah Arendt. Procura-se, assim, problematizar, a partir de tal categoria, os caminhos metodológicos e políticos de uma educação de jovens e adultos comprometida com a emancipação de seus alunos e com a transformação societária, entendendo, portanto, que tais ações se consubstanciam na atualização/radicalização dos pressupostos da Educação Popular em processos formais de escolarização.

Palavras-chave: Educação de Jovens e Adultos; práticas docentes; conscientização.

\section{PRACTICAL TEACHERS IN YOUTH AND ADULT EDUCATION: AWARENESS OR CONVERSION? \\ ABSTRACT}

This article seeks to establish the discussion of the possibilities or otherwise of teaching practices committed to the transformation of educational and corporate relations in formal schooling spaces for young and adult workers. This effort and political commitment on the part of teachers, are strongly linked to Freire's thought and assumptions of Popular Education. The debate will be established from the awareness category, in dialogue with authors of critical and conservative matrices, namely: Paulo Freire, Miguel Arroyo, Marilena Chauí, Giovanni Semeraro, Hugo Lovisolo and Hannah Arendt. Wanted thus questioning from that category, methodological and political paths of young and adult education committed to the emancipation of their students and the corporate transformation, understanding, therefore, that such actions are embodied in the update/radicalization of Popular Education of assumptions in formal schooling processes.

Keywords: Education for Youth and Adults; educational practice; awareness.

1 Doutora em Educação pela Universidade Federal Fluminense. Professora Adjunta da Faculdade de Educação da Universidade Federal do Rio de Janeiro (UFRJ) e integrante do LIEJA (Laboratória de Investigação, Ensino e Extensão em Educação de Jovens e Adultos - UFRJ) e do LEPEH (Laboratório de Estudos e Pesquisas em Ensino de História - UFRJ). E-mail: alenicodemos@ig.com.br 


\section{periferio}

\section{CONSCIENTIZAÇÃO: PARA QUEM, CARA PÁLIDA?}

Em termos da finalidade da Educação de Jovens e Adultos para trabalhadores em processo de escolarização formal, conseguimos captar de forma muito emblemática uma associação direta que se faz entre essa escolarização e um suposto processo de conscientização, protagonizado pelos professores e alcançada pelos estudantes, a partir de uma ação diretiva e consciente dos docentes em suas opções curriculares. Considero importante começar o debate por essa vaga/dúbia ideia da capacidade de conscientização em processos de escolarização e, para tanto, trago inicialmente as contribuições dos críticos ao referencial da Educação Popular nesse aspecto, pois consideram que tais opções curriculares dos docentes são meros processos de coerção/conversão ideológica e não de conscientização.

A conscientização em práticas educativas é apontada pelos críticos da Educação Popular como seu maior paradoxo; eles o fazem apoiando-se em um pressuposto central da perspectiva freiriana de pensamento: quais seriam as possibilidades reais de uma relação simétrica e dialógica entre professor/aluno ou entre letrado/não letrado, entre classe alta/classe baixa? Para alguns autores que abordaremos no artigo, tal possibilidade não seria possível, e esse aspecto constitui um ponto relevante nas críticas em torno das categorias do pensamento freiriano e da Educação Popular e sua materialidade como projeto de transformação das relações educativas e societárias.

Em uma dessas concepções contrárias, a de Hugo Lovisolo (1990), focaliza-se a naturalização da assimetria da relação pedagógica entre professor e aluno. $\mathrm{O}$ autor considera a prática educativa direcionada para adultos essencialmente um paradoxo, já que a educação moderna estabeleceu uma convenção (durkheimiana) em que o natural seria educar crianças, entendendo a prática educativa como intrinsecamente geracional. Nessa concepção, a educação seria o espaço formal para possibilitar aos mais novos o acesso a um produto cultural que deveria ser perpetuado pelas novas gerações. Assim, todas as ações de educação que saíssem dessa lógica geracional não 


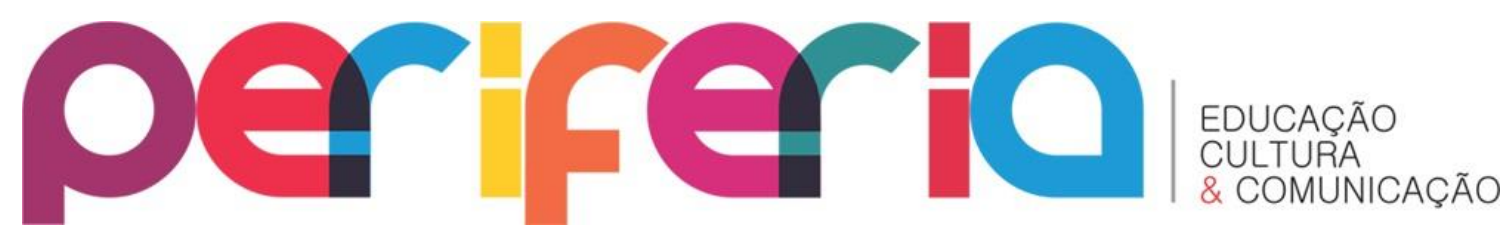

teriam legitimidade ou se constituiriam numa ação desprovida de intencionalidade pedagógica ou reduzida à mera politização da educação. Hannah Arendt, citada por Lovisolo, afirma que

[...] quem quer que queira educar adultos, na realidade, pretende agir como guardião e impedi-los da atividade política. Como não se pode educar adultos, a palavra educação soa mal em política; o que há é um simulacro de educação, enquanto o objetivo real é a coerção sem uso da força (LOVISOLO, 1990, p. 73).

Nessa visão, práticas docentes freirianas e referenciadas na Educação Popular reduziram os educadores a guardiões de ideários distantes e de pouca receptividade no universo cultural das camadas populares. Em razão de tamanho distanciamento, esses intelectuais procurariam impor, pela intervenção educativa, uma concepção política àqueles sujeitos, entendendo, desse modo, a relação entre povo e intelectual com base na dicotomia classe alta/classe baixa. Usando a produção de Berger, Lovisolo destaca uma afirmação do autor sobre a Educação Popular:

É um projeto de indivíduos das classes altas dirigido a uma população de classe baixa. É a segunda desta classe, e não a primeira, a que deve ser conscientizada [...]. Assim, uma suposição crucial do conceito é a de que as pessoas da classe baixa não entendem sua própria situação, necessitam de esclarecimentos a respeito e este serviço pode ser proporcionado por seletos indivíduos das classes altas (LOVISOLO, 1990, p. 79).

Lovisolo continua sua análise indicando que, na educação de adultos, existe uma relação hierárquica que reduz os adultos a serem educados a crianças e/ou rebanhos. Indica ainda que Paulo Freire e seus "discípulos" elaboraram um "drapeamento ideológico" na tentativa de conciliar o inconciliável:

É como se esses argumentos de fato pretendessem remover o paradoxo de se educar adultos, no sentido de considerá-los como rebanho ou como crianças e que, no fundo, significaria o uso da coerção sem o emprego da força que Arendt apontou. Havia então que remover a convenção, que superar os paradoxos que no seu seio estabeleciam. Para isso, Freire e seus discípulos conformaram um drapeado convincente, se medido pelo número de intelectuais dispostos a apoiá-los. Essa ideologia afirma que havia uma forma de educação libertadora que conciliava educadores e educandos na qual ambos aprendiam e que se postula como caminho de construção da 


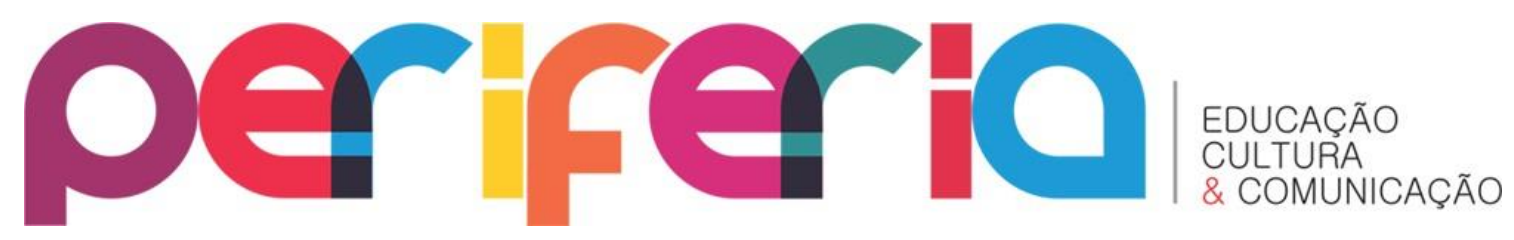

liberdade e como forma de interação de qualquer sociedade de homens livres (LOVISOLO, 1990, p. 81).

Considero que o debate sobre a relação desigual entre letrados e não letrados está presente no pensamento de Paulo Freire, mas em uma dimensão inversa à apontada por Lovisolo. A concepção deste autor, de uma educação de adultos como um paradoxo, é incoerente com o referencial freiriano. Recorrendo à produção de Afonso Celso Scocuglia (s/d), identifico agora alguns elementos do pensamento freiriano analisados pelo autor no que tange à relação entre intelectuais e povo e às possibilidades de simetria dessa relação. Scocuglia (s/d, p. 331) diz:

Como resolver tal problema? Como convencer sem manipular? Como superar o "democratismo populista" na educação? É possível dirigir sem impor? Sim, na ação dialógica. Eis a resposta de Freire. Interessante aprender que a questão dialógica, base da pedagogia freiriana - e um dos fios condutores da explicitação da pedagogicidade inerente aos processos de mudanças sociais -, delineia uma postura conceitual diferente por parte do autor. 0 diálogo que antes transparecia uma ação interclasses, carregando consigo uma carga idealista e romântica, não é admissível como tal, se não como (inter)ação entre "os iguais e os diferentes" contra os antagônicos. Assim, gradativamente a questão dialógica é mergulhada nas lutas sociais e, cada vez mais, categorizada como parte do que o autor denomina ação cultural para a libertação.

Essa afirmação demonstra um aspecto central do pensamento freiriano no que tange à relação entre as classes sociais e as do educador/educando: a incorporação de novas categorias analíticas. A obra de Lovisolo, para justificar as contradições e paradoxos da Educação Popular de base freiriana, não reconhece a progressão analítica do pensamento freiriano e a incorporação de determinadas categorias analíticas, principalmente aquelas vinculadas ao pensamento da dialética marxista. Scocuglia alerta para a necessidade desse cuidado analítico quando se trabalha com a produção de Paulo Freire: "Reafirma-se, uma vez mais, a concreta impossibilidade de se apreender o pensamento freiriano sem compreendê-lo como um movimento cuja única constante é a progressão" (SCOCUGLIA, s/d, p. 332).

A argumentação teórica que sedimenta a relação dialógica entre educador e educando no pensamento freiriano está numa clara aproximação à categoria de luta de 


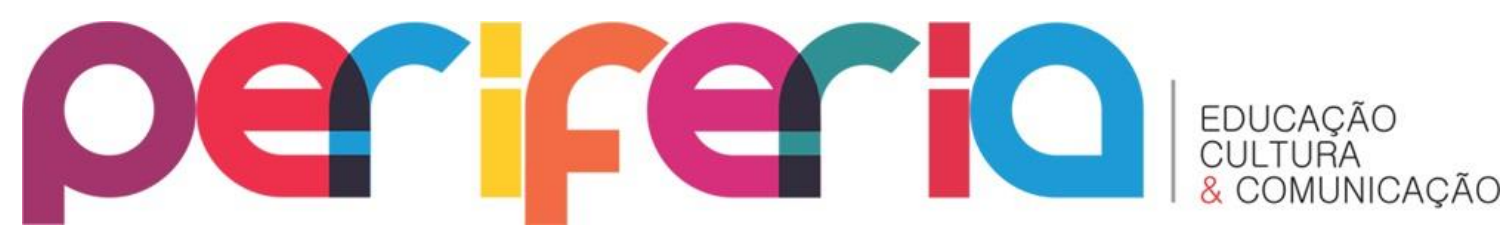

classes do pensamento marxista, principalmente após Pedagogia do Oprimido, em que o autor passa a dialogar de forma promissora com a perspectiva da filosofia dialética e com o próprio marxismo (RAMOS, 2010). Em Pedagogia da Autonomia: saberes necessários à prática educativa (1996), o autor, em sua formulação sobre a gênese cultural do ser humano, lembra claramente a relação intrínseca do homem com as condições materiais de sua existência e, ao mesmo tempo, indica as possibilidades de ação política sobre esse meio. Diz Freire: "Gosto de ser gente porque, inacabado, sei que sou um ser condicionado; mas, consciente do inacabamento, sei que como resultado de operações absolutamente alheias a mim é que posso ir mais além dele" (FREIRE, 1996, p. 53).

Essa afirmação converge com a perspectiva do materialismo histórico, na medida em que este defende a ideia de que o homem se constitui homem a partir dos condicionamentos materiais, indicando que são esses mesmos condicionantes que ensejam as possibilidades de superação da realidade. Então, o inacabamento do homem, segundo a perspectiva de Freire, oferece argumentos para a defesa da sua educação como possibilidade de transformação societária, que, para o autor, deve ser entendida nestes termos:

Seria irônico se a consciência na construção no mundo não implicasse já o reconhecimento da impossibilidade de minha ausência na construção da própria presença. Não posso me perceber como uma presença no mundo, mas, ao mesmo tempo, explicá-la como resultado de operações absolutamente alheias a mim (...) é a posição de quem luta para não ser apenas objeto, mas sujeito também da história (FREIRE, 1996, p. 53-54).

E, nessa direção, conclui:

Nos anos 60, preocupado já com esses obstáculos, apelei para a conscientização não como panaceia, mas como um esforço de conhecimento crítico dos obstáculos, vale dizer, de suas razões de ser. [...] $\mathrm{Na}$ verdade, enquanto aprofundamento da 'crise de consciente' do mundo, dos fatos, dos acontecimentos, a conscientização é exigência humana, é um dos caminhos para a posta em prática da curiosidade epistemológica. Em lugar de estranha, a conscientização é natural ao ser que, inacabado, se sabe inacabado. A questão substantiva não está por isso no puro inacabamento e na 


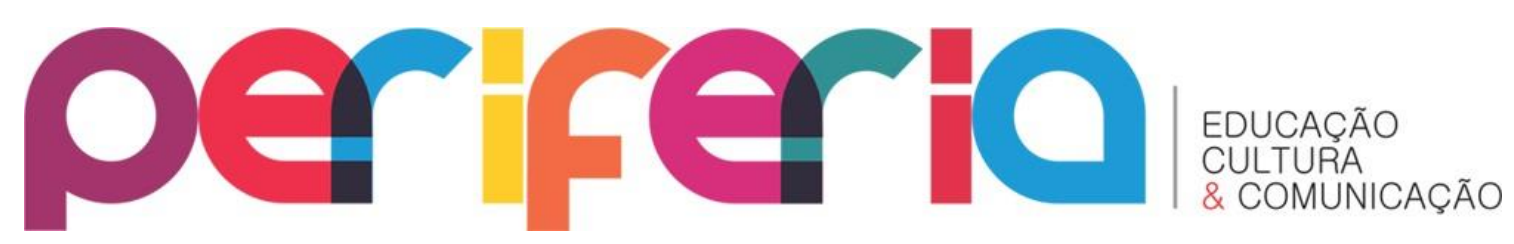

pura inconclusão. A inconclusão, repito, faz parte da natureza do fenômeno vital (FREIRE, 1996, p. 54-55, grifos do autor).

Nesses termos, Freire procura definir o que entende por conscientização e com isso responde às críticas conservadoras que viam o termo de forma reduzida, tratandoo apenas como estratégia de intelectuais de esquerda que procuravam atrair os trabalhadores para as lutas em oposição às classes dominantes. Esse reducionismo não encontra ressonância se compreendermos que classes não proprietárias, como sujeitos do mundo, possuem o direito de saber para além dos elementos aparentes da vida e que a prática educativa, formal ou informal, tem papel preponderante. A conscientização, nos termos referidos, defende a possibilidade de que todos devem ter acesso aos conhecimentos, sejam aqueles criados no seio do saber popular, sejam aqueles produzidos no escopo científico, com a possibilidade de tais saberes serem redimensionados/ressignificados como conteúdos escolares.

Além disso, Freire (2005) defende que todos os educandos têm o direito à criticidade em relação ao que aprendem, o que significa, como indica Kosik (1976), reconhecer que os fenômenos sociais precisam ser tratados com mais investigação e, sobretudo, com mais perguntas, até chegarmos ao essencial. Kosik diz:

O mundo da pseudoconcreticidade é um claro-escuro de verdade e engano. $O$ seu elemento próprio é o duplo sentido. O fenômeno indica a essência e ao mesmo tempo a esconde. A essência se manifesta no fenômeno, mas só de modo inadequado, parcial ou apenas sob certos ângulos e aspectos. $O$ fenômeno indica algo que é ele mesmo e vive apenas graças ao seu contrário. A essência se dá imediatamente; é mediata ao fenômeno e, portanto, se manifesta no fenômeno. O fato de se manifestar revela seu movimento e demonstra que a essência não é inerte nem passiva. Justamente por isso o fenômeno revela a essência. A manifestação da essência é precisamente a atividade do fenômeno (KOSIK, 1976, p. 11).

Dessa forma, o antagonismo não está entre educador (letrado/classe alta) e educando (não letrado/classe baixa); o antagonismo está entre oprimidos e opressores dentro do modelo capitalista de sociedade. A ação dialógica protagonizada por intelectuais e povo na Educação Popular é uma tomada de posicionamento na luta de classes, por meio do reconhecimento pelo educador/professor do seu lugar 


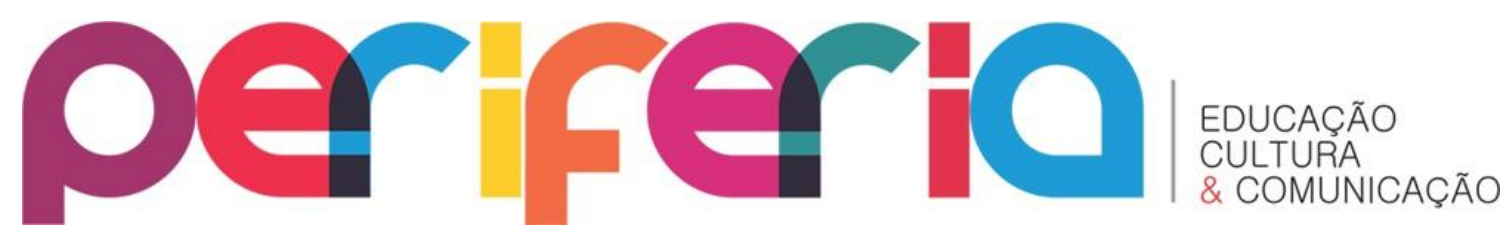

como "educador que também aprende" e, principalmente, de sua condição também de classe trabalhadora e oprimida. Nesse sentido, fica claro que a assimetria na relação entre educador e educando apontada por Lovisolo não pertence à concepção políticopedagógica freiriana dos educadores e intelectuais que comungam dessa concepção e que, ao aderirem ao referencial crítico, estão se posicionando no processo de disputa contra setores dominantes e opressores.

\section{CONSCIENTIZAÇÃO NAS PRÁTICAS DOCENTES NA EJA}

Nos desafios que se colocam para o docente na Educação de Jovens e Adultos trabalhadores e na relação entre educador e educando, está a questão de reconhecer a educação como possibilidade de conscientização dos sujeitos. Esse é um debate intrincado que requer prudência analítica para que não se caia numa visão reducionista dessa delicada e complexa relação que, antes de tudo, é uma relação política e, portanto, deve ser encarada prioritariamente nessa dimensão.

Resgato, nesta oportunidade, algumas reflexões cunhadas por Marilena Chauí em seu texto Ideologia e educação (1980), em que ela tem, entre outras, a intenção de abordar a tese da conscientização nas práticas educativas. Num primeiro momento, a autora procura de forma conceitual discutir o que seria consciência e onde historicamente ela surge como possibilidade de prática social entre os sujeitos. Chauí indica que esta se situa na gênese de constituição do homem moderno, em que o papel da consciência servia como escopo para a definição das ideias de "igualdade, da liberdade e da responsabilidade, isto é, a identidade de todos os homens, garantindo a dissimulação das diferenças de classe” (CHAUÍ, 1980, p. 36). Esse aspecto central na constituição do homem moderno, segundo a autora, vai se dissolvendo ao longo do tempo; nos marcos da ideologia contemporânea, o elemento da consciência perde sua força, transmutado numa lógica cada vez mais funcionalista.

Na ideologia contemporânea o elemento consciência já não exerce qualquer papel, tendo sido substituído pelas ideias de eficiência e de competência no interior dos quadros definidos pela organização. É nisto que a nova ideologia é mais 'honesta' do que a anterior. Nela, a consciência permanece apenas a título de retórica do discurso do 


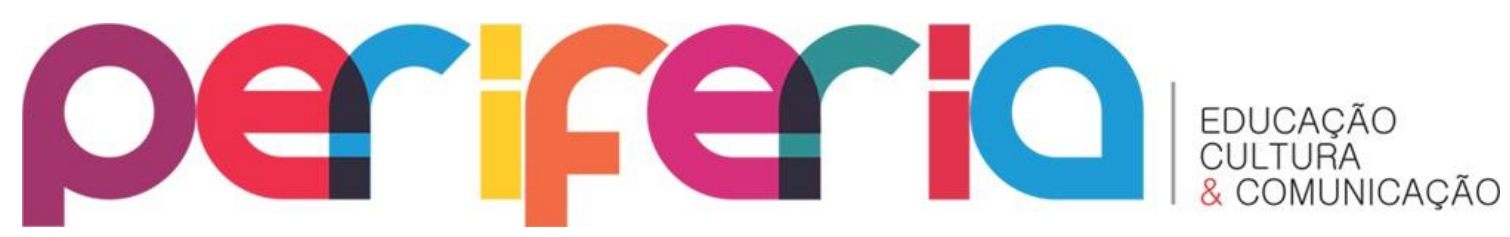

poder (o apelo à consciência dos cidadãos) e como espetáculo oferecido pelo poder (o prêmio de melhor operário, estudante, policial, empresário, professor, cientista, isto é, aos mais conscientes de seus deveres e responsabilidades para com o mundo capitalista) (CHAUÍ, 1980, p. 36).

A conceituação inicial da autora busca problematizar o que seria então a conscientização, encarada como "espírito crítico" que funcionaria como elemento de contestação à consciência, definida nas duas dimensões de espaço/tempo indicadas na última citação. Nessa reflexão, a autora se aproxima das questões colocadas por Lovisolo, principalmente no que tange às denúncias das ações da Educação Popular como possibilidade adestradora dos sujeitos/alunos. Nesse sentido, Marilena Chauí pondera:

Em primeiro lugar, haveria o risco de imaginar o aluno (e a classe social) como uma consciência latente ou virtual, adormecida no seu ser em si e que o professor (ou a vanguarda) viria atualizar ou despertar. Há o risco de atitude iluminista. Em segundo lugar, haveria o risco de imaginar o aluno (e a classe social) como uma consciência de si que, por ignorar-se a si mesma, isto é, não ser ainda para si, tenderia a manifestar-se através de palavras e de ações alienadas como "falsa consciência". Assim sendo, parecerá necessário esperar que a desalienação ou a consciência 'verdadeira' Ihe seja trazida de fora por aqueles que 'sabem'. Há o risco ideológico de diferenciar o aluno (e a classe social) do professor (e da vanguarda) em termos de imaturidade/maturidade, ignorância/saber, alienação/verdade, em suma, diferenciar hierarquicamente e fazendo com que um dos polos seja uma espécie de receptáculo vazio e dócil no qual venha depositar-se um conteúdo exterior trazido pelo outro polo. Com isso, sob o nome de conscientização, reedita-se, sob nova roupagem, o conservadorismo e o autoritarismo da educação que se pretendia combater (CHAUÍ, 1980, p. 36).

Porém, em caminho oposto àquele apontado por Lovisolo, a autora marca ser necessária a manutenção do debate sobre a questão da conscientização e educação, estabelecendo, para isso, outra dimensão de análise, via incorporação da categoria de consciência contraditória como fenômeno presente nos processos de conscientização e de educação. Esse processo identificado por Chauí sopesa a consciência contraditória como um fenômeno que se expressa pela "contradição interna entre uma consciência que sabe e uma consciência que nega o seu saber" (1980, p. 37) e, portanto, uma 


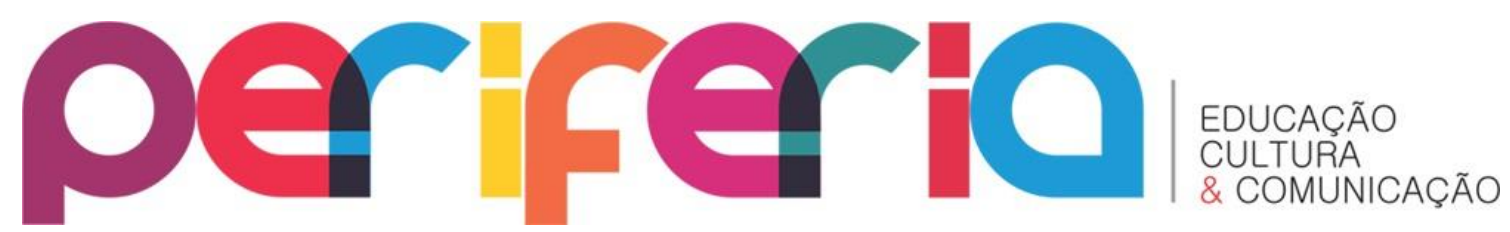

consciência que se manifesta e se materializa nos dois polos do processo de educação: professor e educando. Considera, nesse caso, a possibilidade de uma relação de simetria na percepção da realidade e na leitura crítica dessa realidade. E, relacionando tal fenômeno com o processo educativo, faz as seguintes ponderações:

Não seria mais rica (em termos pedagógicos, políticos e históricos) uma pedagogia que percebesse e interrogasse esse fenômeno no qual um saber real, uma consciência verdadeira das condições objetivas é sufocada internamente sob o peso da adversidade que impede à verdade conhecida e reconhecida propagar-se numa prática e que, ao contrário, cinde essa consciência que sabe fazendo-a produzir atos e discursos negadores de seu saber? (CHAUÍ, 1980, p. 37).

Essa possibilidade de interpretação rompe com um aspecto central nas críticas ao caráter iluminista da Educação Popular, pois essa perspectiva não considera a prática educativa como intervenção ideológica de um grupo sobre o outro e viria de fora do universo de vida e da consciência dos sujeitos a serem educados. A autora conclui:

Em lugar de nos comprazermos no maniqueísmo apaziguador de certas dicotomias, nas quais tanto a ignorância quanto a verdade vêm de fora, tanto o mal (a opressão) quanto o bem (a libertação) também vêm de fora, não seria mais rica uma pedagogia que levasse a serio o fenômeno da consciência contraditória? Por que essa pedagogia seria mais rica (poderíamos mesmo dizer: libertária)? Porque a contradição, sendo interna (tanto do aluno quanto no professor), pode pôr-se em movimento por si mesma sem que precise aguardar a ação de um bom motor-imóvel para movê-la, tirando-a da suposta passividade para levá-la a uma não menos suposta atividade. Uma pedagogia desse tipo não seria iluminista, intervencionista, dirigista, mas tentaria captar aqueles momentos objetivos e subjetivos nos quais a contradição possa vir a explicitar-se (CHAUÍ, 1980, p. 37).

Entendo, como a autora, que determinadas práticas docentes na EJA (assentadas em determinada concepção de mundo e de educação) colocam o professor num lugar em que, juntamente com o aluno jovem e adulto trabalhador, podem-se estabelecer ações/reflexões para o explicitamento das contradições e, a partir delas, a materialização da conscientização na horizontalidade da relação aluno e professor. Assim, considero que a possibilidade da ação dialógica deve estar no cerne da relação 


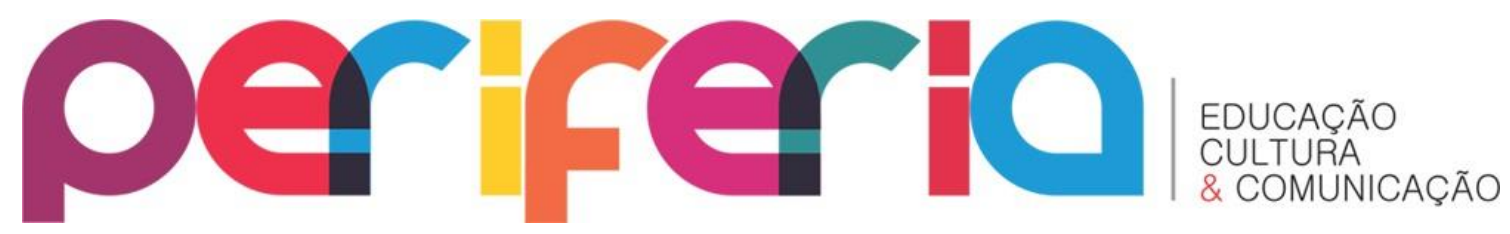

educador/educando e se estrutura na noção freiriana de que ter consciência é estar no mundo; o homem se lança no mundo por meio de sua consciência individual, e essa capacidade não está necessariamente vinculada ao conhecimento formal ou ao domínio do código escrito ou ainda pronta e acabada com base na ação de conversão de terceiros. Nos termos da Educação Popular de base freiriana, os educandos são provocados a assumir o papel de sujeitos cognoscentes (aspecto inerente à condição humana) e, numa ação dialógica e ativa, construir o conhecimento e se apropriar de instrumentos e ferramentas para a leitura da palavra e do mundo (FREIRE, 2005).

A capacidade humana de captar a realidade e de torná-la objeto de conhecimento é feita pela consciência, que medeia essa ação; segundo Semeraro (2009), tal "consciência" nasce, nos contextos latino-americanos, da condição de oprimido e das marcas dos processos de expropriação e violência vivenciada em nossos percursos históricos, pois

[...] o sentido de pertencimento a um destino comum de sofrimento tornou-se um vínculo profundo entre os depauperados desse continente que aprenderam desde cedo a refletir e se organizar para a libertação. Assim, o apego à própria terra e a capacidade de integrar criativamente diferentes culturas e temporalidades transformam-se em instrumentos decisivos para amoldar personalidades indômitas frente às violências dos dominadores e à imposição dos seus modelos. Deriva, acima de tudo, desse pano de fundo o surgimento da 'conscientização' latino-americana, ou seja, a singular formação da Educação Popular que pode ser traduzida como 'politização da consciência'. Muito antes das atividades intelectuais vindas de fora, a formação da consciência dos oprimidos nasce da reação a um sistema que procura dominá-los e das inúmeras iniciativas desencadeadas para se defender (SEMERARO, 2009, p. 49).

Portanto, conscientização em práticas educativas é um processo de construção ativa dos sujeitos envolvidos no processo, educando e educador, em relação simétrica e dialógica, e deve estar assentada na tomada de posição e definição de que projeto político-pedagógico esse professor defende ou se insere, com base na percepção de seu lugar na luta de classe cotidianamente vivenciada nos espaços societários. Essa ideia aparece na obra de Freire, problematizada por Ramos neste trecho: 


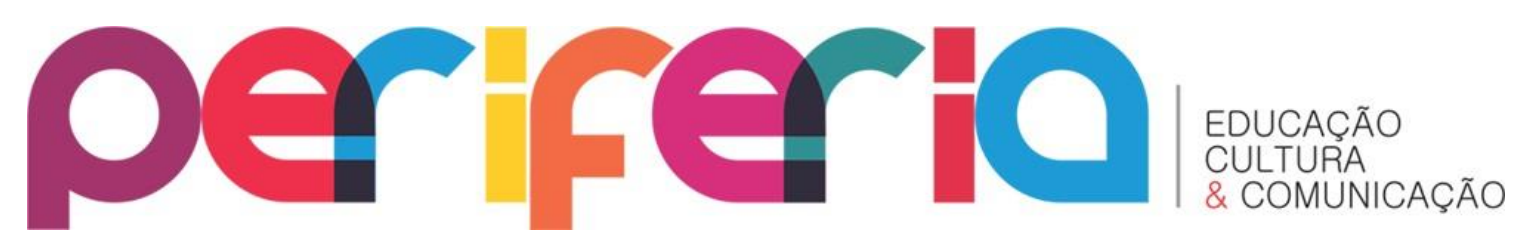

Partindo do pressuposto de que, 'embora diferentes entre si, quem forma se forma e reforma ao formar e quem é formado forma-se e forma ao ser formado' (FREIRE, 1996, p. 23), Freire traz educador e educando, docente e discente não como figuras antagônicas num jogo relacional de oposição, mas como sujeitos inacabados que, no encontro dialético de suas existências, ensinam um ao outro, se fazem, se refazem, se constroem e se reconstroem. Por isso, para ele, não há docência sem discência e ensinar não é transferir conhecimento. Se o homem é sujeito da história, ao contrário de objeto, o educador deve perceber que a prática educativa é capaz de contribuir para a formação de sujeitos críticos e autônomos e rejeita a ideia de educando como depósito de conhecimento. O sujeito crítico observa, julga e intervém sobre aquilo que lhe é proposto. Assim, é o próprio educando quem constrói seu saber (RAMOS, 2010, p. 221-222, grifo nosso).

Podemos ainda dimensionar o debate da conscientização nas práticas escolares na EJA a partir das mudanças históricas na composição dos grupos sociais que, desde os anos 1970, chegam à carreira docente. Considero que essa perspectiva deva ser problematizada também quando apontamos a possibilidade de identificar uma relação pedagógica simétrica, ou não, praticada por professores, já que estamos falando, nas últimas décadas, de educadores e educandos que, no atual contexto histórico, não são tão diferentes entre si, ou melhor, faces de uma mesma moeda de precarização e opressão como classe trabalhadora. Marca trazida principalmente pelo processo de proletarização em que estão inseridos os docentes, seja pelas suas origens sociais, seja pelas condições de trabalho a que estão submetidos nas últimas décadas no cenário educacional brasileiro (NICODEMOS, 2013).

Esse processo de proletarização do magistério, segundo Bittar e Ferreira Jr., pode ser datado e principalmente explicado como consequência direta da ampliação quantitativa da escola pública no país a partir da década de 1970. Segundo esses autores, nesse momento passa a ocorrer uma crise de identidade docente, podendo-se indicar como elementos constitutivos dela dois aspectos significativos: o crescimento numérico da categoria profissional e a mudança de composição de classe:

Nota-se, assim, que nessa época o professorado já não portava o perfil do passado, numericamente inferior e com origem nas camadas médias urbanas e nas próprias elites. Agora, em decorrência das 


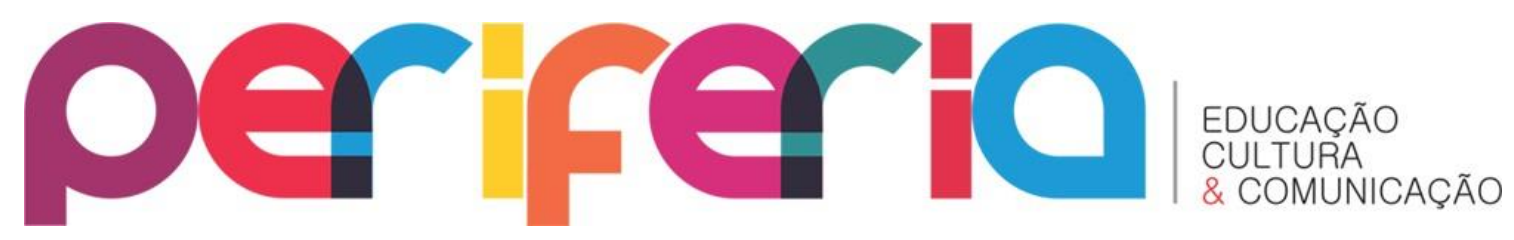

mudanças estruturais do país e das reformas educacionais, ele passava a ser uma categoria muito pouco assemelhada à anterior e submetida a condições de vida e de trabalho bastante diversas (BITTAR; FERREIRA Jr., 2006, p. 1.165).

As reformas educacionais ${ }^{2}$ implementadas pelos governos militares (1964-1985) vinham no sentido de possibilitar a entrada de novos segmentos sociais na escola, a partir da construção de uma estrutura de escolarização densamente vinculada às necessidades de uma modernização conservadora em curso e à construção de uma sociabilidade para o consenso. Nesse sentido, é identificável o impacto dessa política no período sobre os professores na conformação de determinados modelos de práticas docentes, principalmente no âmbito da escola pública.

Pode-se apontar, então, alguns indícios significativos da proletarização do magistério nesse período, entendido aqui como o conjunto de elementos que identificam as mudanças nas condições socioeconômicas que o professor passa a viver: 1. A formação acelerada em licenciaturas curtas; 2. O arrocho salarial e a perda do status social e econômico da categoria; e, por último, 3. A ampliação do controle administrativo e pedagógico sobre o trabalho docente. Para os autores citados, esse controle passa a ocorrer de forma sistemática em função dessa mudança no perfil dos professores:

Um dos aspectos mais relevantes do processo de proletarização vivido pelo magistério brasileiro é que ele desmistificou as atividades pedagógicas do professor como ocupação especializada pertencente ao campo dos chamados profissionais liberais, ocorrendo, de forma acentuada, a paulatina perda do seu status social. Teve início a construção da nova identidade social do professorado do ensino básico, ou seja, a de um profissional da educação submetido às mesmas contradições socioeconômicas que determinavam a existência material dos trabalhadores. Estavam plasmadas, assim, as condições que associariam o seu destino político à luta sindical dos demais trabalhadores (BITTAR; FERREIRA Jr., 2006, p. 1.166-1.167).

Nesse processo, Cury (2009, p. 16) destaca:

2 Com destaque para as mudanças nas estruturas educacionais trazidas pela Lei no 5.692/71 na Educação Básica e pela Lei no 5.540/68 na Educação Superior. 


\section{periferio}

Na ditadura pós-64, o Brasil passou por um grande processo de industrialização e de urbanização. Os quatro anos da então escola primária obrigatória tornaram-se insuficientes. Era preciso estender a escolaridade, e assim o fez a Constituição de 1967, tornando obrigatória aquela entre os sete e quatorze anos. Para isso, era preciso construir escolas, expandir a rede física.

Porém, como aponta o autor, é o momento em que a mesma Constituição de 1967 deixa de destinar recursos obrigatórios para a educação, o que provocou a ampliação de escolarização que teve que se desenvolver com escassos recursos. 0 impacto sobre a remuneração dos professores foi uma das estratégias necessárias para a garantia de tal expansão:

Um dos recursos utilizados foi o achatamento salarial dos professores, o que ajuda a entender os muitos movimentos grevistas nos anos setenta/oitenta. Os professores, de cujos salários saiu boa parte das fontes de financiamento da expansão da rede física dos estabelecimentos do já então ensino de primeiro grau, de lá pra cá, nunca tiveram a devida reparação financeira [...]. Uma carreira nebulosa projetava uma grande ansiedade nos formandos durante a trajetória de qualificação profissional. Formação precária em face do novo perfil do aluno e das condições de trabalho que se foram tornando deficientes determinou um quadro severo na própria profissionalização (CURY, 2009, p. 16).

Tais observações - achatamento salarial e formação docente precarizada implicaram/contribuíram na mudança do perfil dos sujeitos que chegam à carreira docente. Segundo Bittar e Ferreira Jr. (2006), as alterações na origem social do professorado ocorrem com a substituição de um grupo social oriundo das camadas de setores burgueses e de classe média alta para setores ou frações oriundas das classes médias baixas e de camadas de trabalhadores urbanos já atingidos pelo processo de ampliação da escolarização secundária-universitária:

Poder-se-ia pensar que a presença da primeira vertente na composição social dos professores ainda pudesse ser suficiente para manter a profissão no rol dos ofícios liberais. Todavia, esse amálgama social - os de cima (franjas burguesas e extratos das classes médias altas), de um lado, e os de baixo (camadas pauperizadas das classes médias e setores do operariado urbano), do outro - não impediu que se instaurasse um processo perverso e contínuo de proletarização da categoria profissional dos professores públicos estaduais de 10 e 2 응 graus (BITTAR; FERREIRA Jr., 2006, p. 1.168). 


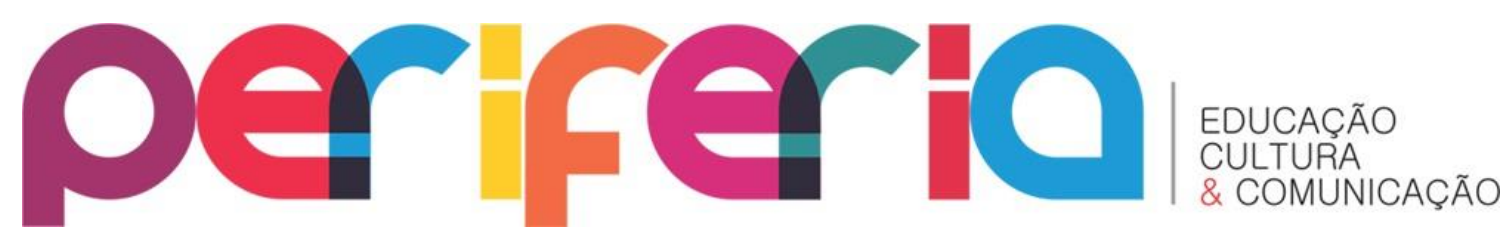

Dessa forma, o professor que identificamos hoje tem sua origem de vida e familiar próxima à de muitos alunos. Nessa nova dinâmica pode-se falar que são setores das classes trabalhadoras atuando com setores da classe trabalhadora. Portanto, a incorporação e o reconhecimento do universo discente não seria a princípio um processo de estranhamento para esse docente. A escola, como espaço de transmissão do que foi produzido pela humanidade na perspectiva assinalada acima, torna-se o espaço privilegiado de transmissão desse conhecimento para os oprimidos. Como Paulo Freire (2005), considero a seleção dos conteúdos e a forma de transmissão desse conteúdo como espaços privilegiados de resistência para as classes subalternas e principalmente de possibilidade de percepção de sua condição de classe oprimida e dos condicionamentos em que está inserida, o que, em última instância, se consubstancia na construção de um currículo crítico e de redimensionamento do papel da aprendizagem como processo de vida da/na escola, cuja afirmação da educação como liberdade é seu principal mote. Na crítica ao modelo de escola que precisamos superar, em sua obra Educação como prática da liberdade (1984), Freire aponta essa dimensão e o esforço que exige dos educadores ao se filiarem a essa opção crítica:

A educação é um ato de amor; por isso, um ato de coragem. Não pode temer o debate. $A$ análise da realidade. Não pode fugir à discussão criadora, sob pena de ser uma farsa. Como aprender a discutir e a debater com uma educação que impõe? Ditamos ideias. Não trocamos ideias. Discursamos aulas. Não debatemos ou discutimos temas. Trabalhamos sobre o educando. Não trabalhamos com ele. Impomos-Ihe uma ordem a que ele não adere, mas se acomoda. Não the propiciamos meios para o pensar autêntico, porque, recebendo as fórmulas que the damos, simplesmente as guarda. Não as incorpora porque a incorporação é o resultado de busca de algo que exige, de quem o tenta, esforço de recriação e de procura. Exige reinvenção (p. 97).

Concluo, assim, considerando que as marcas que a escola imprime no aluno jovem e adulto são, definitivamente, intrincadas e marcantes. Para os alunos jovens e adultos que vivenciam a experiência de recomeço de um processo de aprendizagem formal, os significados, os sentidos e a finalidade desse experimento devem ser 


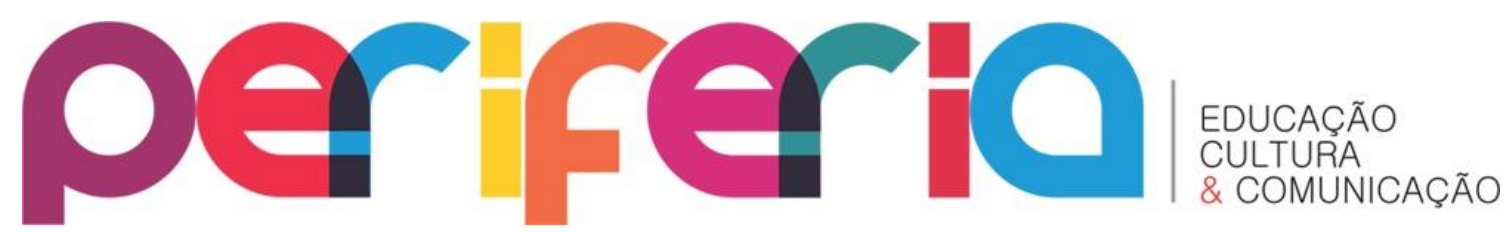

cuidadosamente construídos e sedimentados na relação pedagógica, e o professor tem papel fundamental nesse processo. Nesse contexto, é de extrema importância que a escola discuta a sua ação pedagógica e sua verdadeira intencionalidade, o que implica, por parte do professor, redimensionamento de sua prática docente e principalmente clareza na seleção cultural do conhecimento considerado essencial para o aluno, na perspectiva do projeto de sociedade e de educação em que o docente se insere.

\section{REFERÊNCIAS}

ARROYO, M. A Educação de Jovens e Adultos em tempo de exclusão. Alfabetização e Cidadania, revista de educação de jovens e adultos, $\mathrm{n}^{\circ}$ 11, 2001.

BITTAR, M. A.; FERREIRA Jr., A. A ditadura militar e a proletarização dos professores Educ. Soc., Campinas, v. 27, no 97, p. 1.159-1.179, set./dez. 2006. Disponível em: http://www.cedes.unicamp.br. Acesso em 10 fev. 2013.

CHAUÍ, M. Ideologia e educação. Educ. Soc., Campinas, ano II, no 5, p. 24-40, jan. 1980. CURY, C. À guisa de prefácio. In: BRTTO, V. Professores: identidade, profissionalização e formação. Belo Horizonte: Argumentum, 2009.

FREIRE, Paulo. Ação cultural para a liberdade. 5a ed. Rio de Janeiro: Paz e Terra, 1981.

. Pedagogia da Autonomia: saberes necessários à prática educativa. 16a ed. São

Paulo: Paz e Terra, 1996.

. Pedagogia do Oprimido. 48a ed. Rio de Janeiro: Paz e Terra, 2005.

KOSIK, K. Dialética do concreto. 2ª ed. Rio de Janeiro: Paz e Terra, 1976.

LOVISOLO, H. Educação Popular: maioridade e conciliação. Salvador: Ed. UFBA, 1990.

NICODEMOS, A. O trabalho docente de História no PEJA/RJ: as possibilidades de elaboração, execução e ressignificação de um currículo crítico. Orientador: Clarice Nunes. Tese (Doutorado em Educação). Faculdade de Educação, Universidade Federal Fluminense. Niterói, 2013.

OLIVEIRA, D. A reestruturação do trabalho docente: precarização e flexibilização. Educ. Soc., Campinas, v. 25, no 89, p. 1.127-1.144, set./dez. 2004. Disponível em: http://www.cedes.unicamp.br. Acesso em 10 fev. 2013.

RAMOS, M. Trabalho, educação e correntes pedagógicas no Brasil: um estudo a partir da formação dos trabalhadores técnicos da saúde. Rio de Janeiro: EPSJV/UFRJ, 2010.

SCOCUGLIA, A. C. A progressão do pensamento político-pedagógico de Paulo Freire. Anais do Encontro Paulo Freire y la agenda de la educación latinoamericana en el siglo XXI. s/d. Disponível em: http://biblioteca.clacso.edu.ar/ar/libros/torres/scocuglia.pdf. Acesso em 30 jul. 2012.

SEMERARO, G. Libertação e hegemonia: realizar a América Latina pelos movimentos populares. Aparecida: Ideias e Letras, 2009. 